\title{
Intestinal alkaline phosphatase and inorganic pyrophosphatase activities in the zinc-deficient rat
}

\author{
Bx R. B. WILLIAMS \\ Rowett Research Institute, Bucksburn, Aberdeen AB2 ${ }_{9} S B$
}

(Received I2 March 197I - Accepted $8 \not 3 u l y$ I97I)

\footnotetext{
r. The effect of zinc deficiency on the activities of rat duodenal alkaline phosphatase and inorganic pyrophosphatase has been investigated.

2. $\mathrm{Zn}$ deficiency adversely affected the activity of these enzymes before growth rate and food intake were reduced.

3. The level of food intake was without effect on the activity of alkaline phosphatase but markedly influenced that of inorganic pyrophosphatase.

4. The relevance of changes in the activities of $\mathrm{Zn}$-dependent intestinal enzymes to the food intake of $\mathrm{Zn}$-deficient rats is discussed.
}

Since the initial demonstration by Todd, Elvehjem \& Hart (1934) that zinc is essential for the nutrition of the rat, numerous studies have been made to elucidate the biochemical roles played by this element in this and other species. Almost without exception such studies have been conducted at the intermediate or terminal stages of deficiency as defined by Williams \& Chesters (1970) and thus may have included effects which could have been secondary consequences of deficiency. In the belief that the cessation of growth which occurs within about 4-5 $\mathrm{d}$ after introducing the rat to a low-Zn diet (Williams \& Mills, I970) is not the result of any instantaneous alterations in biochemical or physiological mechanisms at that time, work at this Institute on $\mathrm{Zn}$ deficiency has, to a large extent, been devoted to investigating those effects which occur before growth ceases. The experiments reported here fall in this category.

Alkaline phosphatase (orthophosphoric monoester phosphohydrolase, EC 3.I.3.I) derived from bacteria or various mammalian tissues has been shown to contain $\mathrm{Zn}$ (Mathies, I958; Engström, 196I; Trubowitz, Feldman, Morgenstern \& Hunt, I96r; Plocke, Levinthal \& Vallee, I962), and in this connexion Hove, Elvehjem \& Hart (1940), Kfoury, Reinhold \& Simonian (1968) and Luecke, Olman \& Baltzer (r968) have shown that in $\mathrm{Zn}$-deficient rats there is a reduction in intestinal alkaline phosphatase activity compared with that in $Z$ n-supplemented controls. It was of interest to know whether this effect was an early manifestation of the $\mathrm{Zn}$-deficiency state and, if so, how the reduction in activity of this enzyme was related to the depressed food intake and the cyclical pattern of food consumption observed in the $\mathrm{Zn}$-deficient rat (Williams \& Mills, I970).

Alkaline phosphatase of certain tissues has been shown to have inorganic pyrophosphatase (pyrophosphate phosphohydrolase, $E C$ 3.6.I.I) activity (Cox \& Griffin, 1965; Moss, Eaton, Smith \& Whitby, 1967; Fernley \& Walker, 1967). Inorganic pyrophosphate is released during the course of many reactions in major pathways of 
metabolism which include polynucleotide, phosphatide, co-enzyme and glucuronide synthesis, and a reduction in the rate at which this metabolite is removed may have an adverse effect on the rates of these reactions. It was decided therefore to determine whether a reduction in the activity of inorganic pyrophosphatase had occurred in the intestine of the $\mathrm{Zn}$-deficient rat, and whether any effect observed was related to alkaline phosphatase activity. Due consideration was paid to the necessity for controlling both rate and level of food intake. Where necessary, use was made of the feeding device described by Quarterman, Williams \& Humphries (1970).

\section{EXPERIMENTAL}

\section{Animals and treatment}

Male and female Hooded Lister weanling rats of the Rowett Institute strain, maintained under minimal disease conditions, were housed individually in Perspex and glass cages with access ad lib. to distilled water and were given the purified diet previously described (Williams \& Mills, 1970). The basal diet was supplemented with $40 \mu \mathrm{g} \mathrm{Zn/g}$ as $\mathrm{ZnSO}_{4} \cdot{ }_{7} \mathrm{H}_{2} \mathrm{O}$. Food intake was measured daily and live weights were recorded twice weekly or daily according to experimental demands. The basal $\mathrm{Zn}$-deficient diet was offered $a d l i b$. in Expt $\mathrm{I}$, or in restricted quantities in Expt 2 (see p. 125).

\section{Chemical methods}

The $\mathrm{Zn}$ content of the diets was determined by atomic absorption spectrophotometry after wet-ashing the samples with a mixture of nitric, perchloric and sulphuric acids.

Protein determinations were made by the method of Lowry, Rosebrough, Farr $\&$ Randall (1951) using bovine serum albumin as the standard.

\section{Preparation of tissue}

Rats were killed by a blow to the head and a $100 \mathrm{~mm}$ length of the intestine was removed, beginning at a point $50 \mathrm{~mm}$ from the pyloric end of the stomach. The sample of intestine was rapidly cut into small pieces of rather less than Io $\mathrm{mm}$ length, which were gently squeezed to expel any surplus fluid and partly digested food. After being weighed, the pieces were placed in $5 \mathrm{ml}$ ice-cold $0.25 \mathrm{M}$-sucrose solution and homogenized in a loose-fitting Potter-Elvehjem type all-glass homogenizer. The resulting suspension was filtered through two layers of surgical gauze to remove the unbroken muscular tissue. A portion $(0.5 \mathrm{ml})$ of the filtered suspension was then added to a further $19.5 \mathrm{ml}$ of the cold sucrose solution and the mixture re-homogenized in a close-fitting glass homogenizer $(0.05 \mathrm{~mm}$ clearance). This suspension, preserved in an ice-bath, was used for both enzyme assays. During all the experiments, attempts were made to have a constant period of time between killing the animals and assaying the enzyme activity. 


\section{Preparation of buffer}

In many experiments, in which enzyme activities have been investigated over a wide $\mathrm{pH}$ range, it has been the practice to use several different buffer systems to cover the $\mathrm{pH}$ range under test. This has disadvantages, not the least of which is the possibility that different metal-binding capacities of alternative buffer solutions may

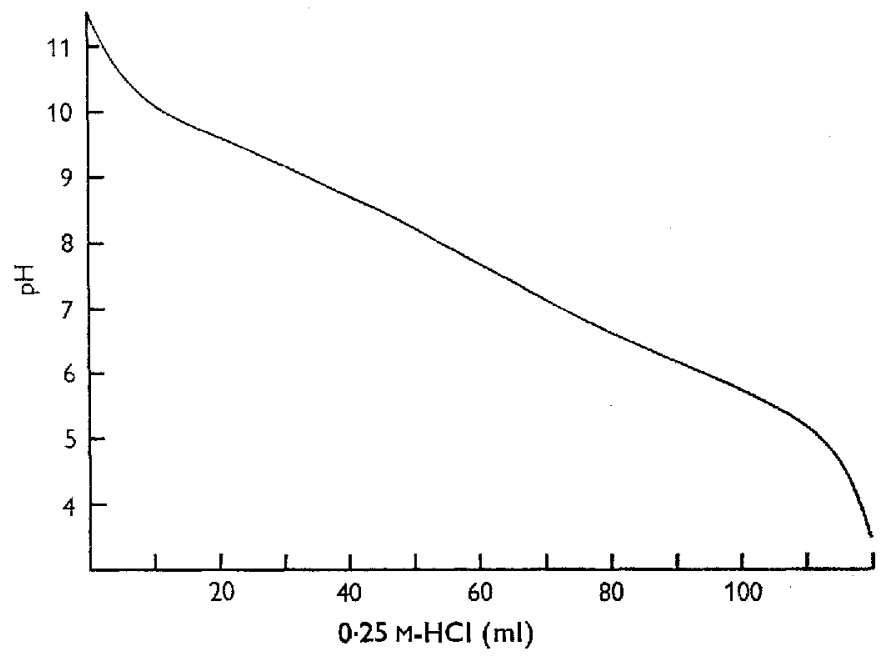

Fig. I. Titration curve of $100 \mathrm{ml}$ triethanolamine-borate-maleate mixture (sec this page) against $\mathrm{HCl}$.

influence activity in the assay of metal-dependent enzymes. It was therefore necessary to develop a wide-range buffer system which would satisfy the following criteria: (a) have a low metal-binding capacity, $(b)$ be capable of adjustment about the $\mathrm{pH}$ range $5^{-10}$, and also meet as far as possible the requirements laid down by Britton \& Robinson (I93I) that differences in the $\mathrm{p} K$ values of the components should be about $\mathrm{I} \cdot 2$.

Triethanolamine $\left(\mathrm{p} K{ }_{7} \cdot 76\right)$ was chosen as the basis of this buffer system, with the addition of maleate $\left(\mathrm{p} K_{2}=6.24\right)$ and borate $(\mathrm{p} K=9 \cdot 24)$. The composition and preparation of this buffer was as follows. In about $200 \mathrm{ml} \mathrm{H}_{2} \mathrm{O}$ were dissolved $7 \cdot 46 \mathrm{~g}$ triethanolamine and $4.768 \mathrm{~g} \mathrm{Na} \mathrm{B}_{4} \mathrm{O}_{7} \cdot \mathrm{IOH}_{2} \mathrm{O}$. A solution of $5.805 \mathrm{~g}$ maleic acid in I $25 \mathrm{ml} \mathrm{M-NaOH}$ was then made; the two solutions were mixed and the mixture was diluted to $500 \mathrm{ml}$. Portions of the mixture (100 $\mathrm{ml}$ each) were titrated to the desired $\mathrm{pH}$ with $0.25 \mathrm{M}-\mathrm{HCl}$, and this solution was further diluted to $200 \mathrm{ml}$ with $\mathrm{H}_{2} \mathrm{O}$. The final concentrations of reagents were: triethanolamine, $0.05 \mathrm{M}$; borate, $0.0125 \mathrm{M}$; maleate, $0.05 \mathrm{M}$.

The titration curve against $\mathrm{HCl}$ was virtually rectilinear over the range $\mathrm{pH} 5^{\cdot} 5^{-10} \cdot 0$ (Fig. I), though minor points of inflexion were detectable at $\mathrm{pH}$ values of 6.5 and 8.5 .

\section{Enzyme assays}

Alkaline phosphatase activity was measured at $\mathrm{pH}$ ro. $\mathrm{O}$ in $\mathrm{r} \cdot \mathrm{O} \mathrm{ml}$ of the buffer described above. The concentration of substrate ( $p$-nitrophenylphosphate; Sigma 
London Chemical Co. Ltd) was $5.5 \mathrm{~mm}$, and $\mathrm{Mg}^{2+}$ was added as $\mathrm{MgCl}_{2}$ to give a concentration of $0.5 \mathrm{~mm}$. When $\mathrm{Zn}^{2+}$ was added, this was as $\mathrm{ZnSO}_{4}$ in $0.1 \mathrm{ml} \mathrm{H} \mathrm{H}_{2} \mathrm{O}$, the same volume of $\mathrm{H}_{2} \mathrm{O}$ alone being added to control tubes. After addition of $\mathrm{O} \cdot \mathrm{I} \mathrm{ml}$ of the homogenate and incubation at $37^{\circ}$ for Io min, the extinction of the $p$-nitrophenol liberated was measured at $405 \mathrm{~nm}$ after the addition of $10 \mathrm{ml} 0.025 \mathrm{M}-\mathrm{NaOH}$.

Inorganic pyrophosphatase assays were done in the triethanolamine buffer at $\mathrm{pH} 7 \cdot 6$. In each assay, to $1 \cdot 0 \mathrm{ml}$ of the buffer, containing $3.3 \mathrm{mmol} / 1 \mathrm{Mg}^{2+}$ as $\mathrm{MgCl}_{2}$, was added $O^{\circ} \mathrm{I} \mathrm{ml} \mathrm{H}_{2} \mathrm{O}$ or, in order to overcome inhibitory effects of heavy metal contaminants, $0.1 \mathrm{ml}$ of a solution of disodium ethylenediamine-tetraacetate (EDTA) to give a final concentration of $0.2 \mathrm{~mm}$. The tubes were cooled to $0^{\circ}$ in an ice-bath and $0.1 \mathrm{ml}$ of the homogenate was added, followed by the addition of $\mathrm{r} \cdot 0 \mathrm{ml} 3.3 \mathrm{mM}-$ tetrasodium pyrophosphate. After incubation for 10 min at $37^{\circ}$ the reaction was stopped by the addition of $2 \cdot 2 \mathrm{ml}$ ice-cold water followed by $0.2 \mathrm{ml} 5 \mathrm{M}_{2}-\mathrm{H}_{2} \mathrm{SO}_{4}$. After the addition of $0.2 \mathrm{ml} 5 \%$ sodium molybdate solution the tubes were kept at $0^{\circ}$ for at least $15 \mathrm{~min}$. They were then centrifuged at $500 \mathrm{~g}$ for $5 \mathrm{~min}$, to yield clear supernatant liquids. The phosphate liberated in the whole of the supernatant liquid was measured by the 'room temperature' method of Bartlett (1959). Blank values were determined on samples to which the homogenate was added after the addition of the $\mathrm{H}_{2} \mathrm{SO}_{4}$.

Preliminary experiments had shown that the pyrophosphatase activity in this buffer system was maximal at $\mathrm{pH} 7 \cdot 6$. The system was activated by EDTA over the $\mathrm{pH}$ range $5.5-10.0$, and activation at $\mathrm{pH} 7.6$ was maximal at a concentration of $0.2 \mathrm{~mm}$.

The low molarity of the buffer would be unlikely to introduce errors due to phosphotransferase activity (Wilson, Dayan \& Cyr, 1964).

\section{The synchronization of the cycle of food intake in Zn-deficient rats}

The quantity of food consumed by a $\mathrm{Zn}$-deficient rat varies greatly from day to day, and in a sufficiently long experimental period a cyclic pattern of food intake is detectable. Although the mean duration of the cycle is approximately $3.5 \mathrm{~d}$ (Williams \& Mills, 1970), individual animals deviate in both phase and amplitude from the mean pattern. In a group of animals, therefore, it would be difficult to select, on any one day, sufficient animals for experimental purposes that would be at the same phase of the cycle. This situation complicates the management of experiments in which it is desired to separate metabolic effects due to deficiency of a specific nutrient from those arising from daily differences in food consumption. It was found, however, that the difficulty of ensuring that all the animals were 'in phase' could be overcome by the imposition of an artificial cycle of food intake of fixed duration on a large group of $\mathrm{Zn}$-deficient rats. It was inconvenient to attempt to impose the natural cycle of $3.5 \mathrm{~d}$; therefore a cycle of $4 \mathrm{~d}$ was selected. Based upon observed patterns of food consumption in previous experiments (Williams \& Mills, 1970), the offering of 2, $8.5,8.5$ and $5.5 \mathrm{~g} \mathrm{Zn}$-deficient diet on successive days to rats of about $100 \mathrm{~g}$ bodyweight gave a reasonable imitation of the situation obtained by feeding ad lib., with negligible rejection of food. The total amount offered in each $4 \mathrm{~d}$ period was thus equivalent to four times the mean daily intake of $\mathrm{Zn}$-deficient rats of the body-weight 
used in these experiments. It was possible to maintain this artificial pattern of intake for five complete cycles before any evidence of a break-away became apparent. Even at this point, however, only a very few animals were affected, and Fig. 2 illustrates by a few examples the scale of the divergence by individual rats from the imposed cycle. By this means, it was possible to obtain a sufficient number of animals at any phase of the cycle for assay of tissue enzyme activity on any selected day.
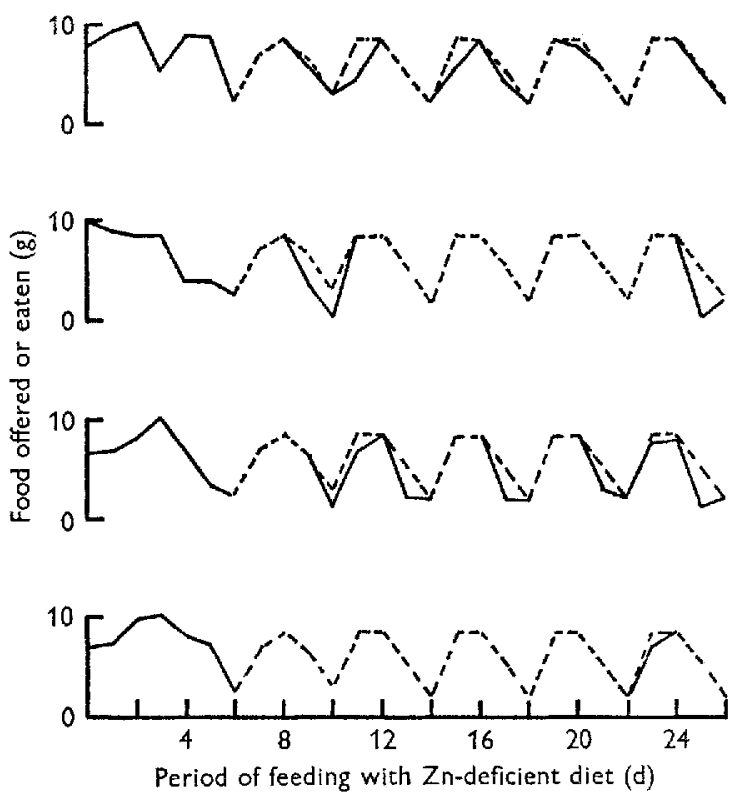

Fig. 2. Effect of imposition of fixed duration cycle on food consumption of zinc-deficient rats. Cycle imposed from day 6 of deficiency state. ----, food offered; - - - voluntary intake.

\section{Expt $\mathrm{I}$. The effects of incipient $Z n$ deficiency on duodenal alkaline phosphatase and inorganic pyrophosphatase activities}

In this experiment twenty-four male weanling rats were offered the $\mathrm{Zn}$-supplemented diet until the group had attained a mean weight of $75 \mathrm{~g}$. At this point the animals were transferred to the $\mathrm{Zn}$-deficient diet and were killed in groups of four on each of days $\mathrm{I}, 3,4,5$ and 8 of the deficiency period, the first group being killed $24 \mathrm{~h}$ after being offered the $\mathrm{Zn}$-deficient diet. The remaining group of four rats was maintained on the $\mathrm{Zn}$-deficient diet for $2 \mathrm{I} \mathrm{d}$; results for this group were compared with those of a control group of four $\mathrm{Zn}$-supplemented rats of similar age given the same quantities of food by a continuous feeder device (Quarterman et al. 1970).

\section{Expt 2. Food intake and intestinal alkaline phosphatase and inorganic pyrophosphatase activities in the Zn-deficient rat}

In order to assess with a greater degree of certainty the effects of the level of food intake on the activities of these enzymes in the $\mathrm{Zn}$-deficient rat, twenty-four female weanling rats were given the $\mathrm{Zn}$-supplemented diet $a d l i b$. until they reached a weight 
of about $75 \mathrm{~g}$. They were then offered the $\mathrm{Zn}$-deficient diet until growth ceased 4-5 d later. From this point the cycles of food intake of all the rats were synchronized as described earlier. On the completion of five cycles, groups of six rats were killed on each of the next $4 \mathrm{~d}$, the first group being killed $24 \mathrm{~h}$ after being offered $2 \mathrm{~g}$ of the diet.

\section{RESULTS}

The results of Expt I show (Table I) that the alkaline phosphatase activity had declined by the 3 rd day, and that it then showed a transient rise before falling to about half the original activity by the $5^{\text {th }}$ day of the deficiency period. These changes

\section{Table I. Effect of developing zinc deficiency on the activities of intestinal alkaline phosphatase and inorganic pyrophosphatase in the rat}

(Mean values with their standard errors)

\begin{tabular}{|c|c|c|c|c|c|c|c|}
\hline \multirow[b]{2}{*}{ Day } & \multirow[b]{2}{*}{ Treatment* } & \multirow{2}{*}{$\begin{array}{l}\text { No. of } \\
\text { rats } \\
\text { weighed }\end{array}$} & \multirow{2}{*}{$\begin{array}{l}\text { Mean } \\
\text { body-wt } \\
\text { (g) }\end{array}$} & \multirow{2}{*}{$\begin{array}{l}\text { Mean food } \\
\text { intake in } \\
24 \text { h before } \\
\text { death } \\
\text { (g) }\end{array}$} & \multirow{2}{*}{$\begin{array}{c}\text { Alkaline } \\
\text { phosphatase } \\
(\mu \mathrm{mol} p- \\
\text { nitrophenol } \\
\text { liberated } / \mathrm{mg} \\
\text { protein min })\end{array}$} & \multicolumn{2}{|c|}{$\begin{array}{l}\text { Inorganic pyrophosphatase } \\
\text { ( } \mu \text { mol phosphate liberated } \\
\text { mg protein min) }\end{array}$} \\
\hline & & & & & & - ED'TA & $\begin{array}{c}+0.2 \mathrm{mM}- \\
\text { EDTA }\end{array}$ \\
\hline I & $\begin{array}{l}\text { Zn-deficient } \\
\text { diet ad lib. }\end{array}$ & 16 & $76 \cdot 7 \pm 2 \cdot 0$ & $7 \cdot 70 \pm 0.52$ & $0.72 \pm 0.12$ & $0.93 \pm 0.19$ & $0.95 \pm 0.02$ \\
\hline 3 & & 16 & $86 \cdot 9 \pm 2 \cdot 2$ & $8.5^{8} \pm 0.3^{8}$ & $0.36 \pm 0.02$ & $0.52 \pm 0.02$ & $0.80 \pm 0.02$ \\
\hline 4 & & I 2 & $93 \cdot 5 \pm 2 \cdot 7$ & $9.89 \pm 0.45$ & $0.63 \pm 0.12$ & $0.62 \pm 0.04$ & $0.83 \pm 0.02$ \\
\hline 5 & & 8 & $91 \cdot 3 \pm 2 \cdot 5$ & $7.35 \pm 0.87$ & $0.34 \pm 0.03$ & $0.48 \pm 0.02$ & $0.75 \pm 0.05$ \\
\hline 8 & & 4 & $93.0 \pm 4.4$ & $10.05 \pm 0.78$ & $0.35 \pm 0.03$ & $0.38 \pm 0.03$ & $0.54 \pm 0.05$ \\
\hline $2 I$ & & 4 & $92 \cdot 0 \pm 6 \cdot 8$ & $3.40 \pm 0.68$ & $0.47 \pm 0.03$ & $0.39 \pm 0.01$ & $0.50 \pm 0.01$ \\
\hline $2 \mathrm{I}$ & $\begin{array}{l}\text { Zn-supplemented } \\
\text { diet (continuous } \\
\text { pair-fed) }\end{array}$ & 4 & $92 \cdot 8 \pm 5 \cdot 5$ & $4^{\prime} 03 \pm 2 \cdot 11$ & $0.82 \pm 0.04$ & $0.54 \pm 0.05$ & $0.59 \pm 0.0 \mathrm{I}$ \\
\hline
\end{tabular}

occurred before food intake and growth were affected. The results of the pyrophosphatase assays suggest that there may have been a relationship between the activity of this system and the stage of development of the deficiency state when assessed on the unactivated samples. With the EDTA-treated samples the response was slower. A further complication in the interpretation of the results of the pyrophosphatase assay was that during the course of this experiment it was noted that in individual assays, besides any effect of $\mathrm{Zn}$ deficiency on pyrophosphatase activity, there also appeared to be a relation between the activity of this enzyme and the amount of food eaten by the animal during the $24 \mathrm{~h}$ preceding its death.

These results showed that $\mathrm{Zn}$ deficiency caused a rapid fall in the activity of intestinal alkaline phosphatase without concomitant changes in growth rate or food intake. As any aberrations in nutrient absorption resulting from the reduction in enzyme activity could take some days to become manifest this would suggest that the swift decline in the activity of this enzyme may have been connected with the fall in food intake which occurred shortly afterwards.

The results of Expt 2 are shown in Fig. 3. It is clear that no relationship existed 
between the phase of the food intake cycle and the activity of alkaline phosphatase. On the other hand, inorganic pyrophosphatase activity rose to a maximum on the 2nd day of the cycle and declined slowly to the $4^{\text {th }}$ day; the difference in activity between days I and 2 being statistically significant $(P<0 \cdot 0 x)$. Although the activity of this enzyme for the remainder of the cycle was significantly different from the activity at day I, the differences between the values on days 2 and 3 were not significant, irrespective of the use of EDTA in the assay system. A significant fall in pyrophosphatase activity did, however, occur in the activated system between days 3 and 4 of the cycle.

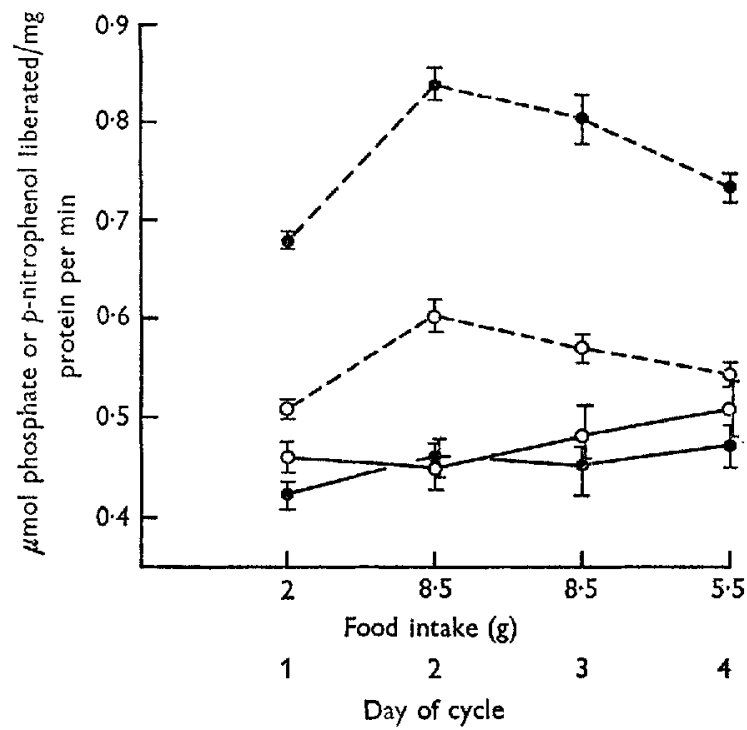

Fig. 3. Effect of level of food intake on alkaline phosphatase and inorganic pyrophosphatase activities in the duodenum of zinc-deficient rats. $\mathrm{O}-\mathrm{O}$, alkaline phosphatase; alkaline phosphatase in presence of $50 \mu \mathrm{M} Z \mathbf{Z n}$; --- 0 , inorganic pyrophosphatase; inorganic pyrophosphatase in presence of $0.2 \mathrm{mM}-\mathrm{EDT}$. Each point represents the mean of six values with its standard error.

In this experiment the effect of the in vitro addition of small quantities of $\mathrm{Zn}$ on the activity of intestinal alkaline phosphatase was investigated, since an earlier report (Kfoury et al. 1968) had indicated that a positive response might be obtained at an added $\mathrm{Zn}$ concentration of $0.5 \mathrm{~mm}$. Preliminary experiments using the triethanolamine buffer system showed that concentrations of $Z n$ above $50 \mu \mathrm{M}$ always caused considerable inhibition. In the present experiment $50 \mu \mathrm{M}-\mathrm{Zn}$ caused marginal inhibition (about $7 \%$ ) in three out of four groups of rats, although the differences were not significant.

\section{DISCUSSION}

The results of these expcriments are in agreement with those of earlier workers which show that $Z \mathbf{n}$ deficiency causes a decline in the alkaline phosphatase activity of the rat intestine. The present experiments show that this effect occurs very early during the onset of the deficiency state, before growth and food consumption are 
affected. This result is closely paralleled by earlier findings (Mills, Quarterman, Williams, Dalgarno \& Panić, 1967) that rat pancreatic carboxypeptidase activity declines very early during incipient $\mathrm{Zn}$ deficiency and that this decline is not a consequence of a reduced food intake.

Interpretation of the effect of $\mathrm{Zn}$ deficiency on inorganic pyrophosphatase activity is complicated by the effects of food intake on this system. Although it would appear that incipient $\mathbf{Z n}$ deficiency reduces the activity of this system, particularly when assessed on the unactivated samples, this effect can also occur as a result of restriction of food intake. The results of Expt 2 show that alkaline phosphatase and inorganic pyrophosphatase activities measured after a relatively prolonged deficiency period continue to show differences in their response to changes in food intake.

In view of the evidence, cited earlier, that alkaline phosphatase of a variety of tissues possesses pyrophosphatase activity, it was surprising that the activities of these two systems were not more closely related in these experiments. There is, so far, only indirect evidence that intestinal inorganic pyrophosphatase activity is dependent on the presence of $\mathrm{Zn}$ (Hove et al. 1940). The results obtained in the present experiments cannot be regarded as substantiating that earlier work. It is possible that the presence of $\mathrm{Zn}$ at structural or functional sites in the alkaline phosphatase molecule is not necessary for pyrophosphatase activity. If this were indeed so, and it were considered that the differences in pyrophosphatase activity in response to altered food intakes were related to changes in the production of a $\mathrm{Zn}$-free apoenzyme, this would hardly be compatible with the observation that restriction of food intake was without influence on intestinal alkaline phosphatase activity in the normal rat (Luecke et al. r 968 ). The conclusion which must be reached is that a proportion, at least, of the inorganic pyrophosphatase activity cannot be associated with alkaline phosphatase.

The relationship between food intake and pyrophosphatase activity is also of interest in connexion with the possibility that $\mathrm{Zn}$ deficiency may result in a general decline in protein synthesis. Direct evidence that this may be so is confined to studies on micro-organisms, e.g. Neurospora (Nason, Kaplan \& Colowick, I95I) and Euglena gracilis (Price \& Vallee, I962; Wacker, 1962). In the rat, Williams \& Chesters (1970) were able to demonstrate that rates of protein synthesis in certain tissues showed a small decline very early in $\mathrm{Zn}$ deficiency, although these effects appeared to be organ-specific. The fact that, in the present experiments, it would appear that the $\mathrm{Zn}$-deficient rat can accommodate itself to differences in food intake by adjustment of the activity of a specific enzyme protein indicates that, in one tissue at least, rates of protein synthesis may increase when necessary. If this were indeed so, then it could be argued that the decline in alkaline phosphatase activity is the direct result of a lack of $\mathrm{Zn}$ and not merely a reduced production of the apoenzyme. $A$ similar conclusion was reached as a result of earlier studies on the effects of $\mathrm{Zn}$ deficicncy on the production of proteolytic enzymes in the rat pancreas (Mills et al. 1967 ; Mills, Quarterman, Chesters, Williams \& Dalgarno, 1969). An alternative explanation would be that high levels of food intake increase the amount of free amino acids available to chelate heavy metal inhibitors of the pyrophosphatase activity. In this respect it was found that pyrophosphatase activity was markedly more sensitive to traces of copper than was 
alkaline phosphatase even when both activities were measured at the same $\mathrm{pH}(7 \cdot 5)$, thus eliminating any differences due to the ionic state of the metal (R. B. Williams, unpublished observations). The recent work of Snaith \& Levvy (1969) with $\alpha$-mannosidase has strongly emphasized the importance of competitive metal antagonisms with respect to the function of $\mathrm{Zn}$-activated enzymes.

The failure to detect any activating effect of added $\mathrm{Zn}$ on the alkaline phosphatase of $\mathrm{Zn}$-deficient rats was somewhat puzzling in view of the report from Kfoury et al. ( 1968 ) that additions of $0.5 \mathrm{mmol} \mathrm{Zn} / \mathrm{l}$ caused similar percentage increases in the activity of this enzyme in both $\mathrm{Zn}$-deficient and control mucosal homogenates. This difference could be related to the use of a different buffer system, and in this connexion Luecke et al. (1968) found that the alkaline phosphatase activity of a homogenate of rat intestine could be greatly increased by the use of veronal or 2-amino-2-methyl-Ipropanol compared with glycine as buffer. This follows from the demonstration by Plocke \& Vallee (1962) that alkaline phosphatase from Escherichia coli could be activated or inhibited by metal ions in a way that suggested a relationship between observed activity and the stability constants of the metal ion complex formed with the components of the buffer systems used.

The relevance of changes in the activity of these enzymes to the functioning of the gastro-intestinal tract of the $\mathrm{Zn}$-deficient rat is uncertain. It may be only coincidence that, with both pancreatic carboxypeptidase and intestinal alkaline phosphatase, a decline to about one-half of the initial activity occurs by about the 5 th day of the deficiency state and is followed immediately by a fall in food intake and development of the cyclical pattern of feeding. This suggests that a genuine defect in nutrient absorption or metabolism may have occurred.

Alternatively, it may be considered that the declines in the activity of alkaline phosphatase observed in the present experiment and of pancreatic carboxypeptidase (Mills et al. I967) are of little consequence to the intestinal metabolism of the rat. Both experiments have shown that high intakes of food and normal growth occurred during the initial $\mathrm{Zn}$-depletion state when the activities of these enzymes were declining and when digestion and absorption must have been normal or very nearly so. At later stages of the deficiency state, when food intake was variable but when little change in weight of the animal occurred, it was clear that the mean daily food intake was suffcient for maintenance of energy equilibrium. It seems therefore that, at peaks of the cycle when food intake is greater than maintenance requirement, digestion and absorption are unimpaired but storage of excess energy is restricted by the failure of growth induced by $\mathrm{Zn}$ deficiency, and in consequence further food intake is inhibited. As a corollary to this it would appear that the depression in food intake which occurs shortly after introducing the rat to the $\mathrm{Zn}$-deficient diet is a consequence of growth failure, rather than the reverse. This is in accord with the observations of Williams \& Chesters (1970) that during the incipient Zn-deficiency state a rapid fall in DNA synthesis occurs.

The author acknowledges the interest and support of Dr C.F. Mills during this investigation and also the excellent technical assistance of Miss Irene Hird. 


\section{REFEREN CES}

Bartlett, G. R. (r959). F. biol. Chem, 234, 466.

Britton, H. T. S. \& Robinson, R. A. (I93 I). F. chem. Soc. p. 1456 .

Cox, R. P. \& Griffin, M. J. (1965). Lancet ii, ror 8.

Engström, L. (I961). Biochim. biophys. Acta 52, 36 .

Fernley, H. N. \& Walker, P. G. (1967). Biochem. F. I04, IoI I.

Hove, E., Elvehjem, C. A. \& Hart, E. B. (1940). F. biol. Chem. r34, 425.

Kfoury, G. A., Reinhold, J. G. \& Simonian, S. J. (1968). F. Nutr. 95, 102.

Lowry, O. H., Rosebrough, N. J., Farr, A. L. \& Randall, R. J. (195I). F. biol. Chem. 193, 265.

Luecke, R. W., Olman, M. E. \& Baltzer, B. V. (1968). F. Nutr. 94, 344.

Mathies, J. C. (1958). F. biol. Chem. 233, I121.

Mills, C. F., Quarterman, J., Chesters, J. K., Williams, R. B. \& Dalgarno, A. C. (1969). Am. J. clin. Nutr. 22, 1240.

Mills, C. F., Quarterman, J., Williams, R. B., Dalgarno, A. C. \& Panić, B. (r967). Biochem. F. roz, 7 Iz.

Moss, D. W., Eaton, R. H., Smith, J. K. \& Whitby, L. G. (1967). Biochem. F. 102, 53.

Nason, A., Kaplan, N. O. \& Colowick, S. P. (195I). F. biol. Chem. r88, 397.

Plocke, D. J., Ievinthal, C. \& Vallee, B. L. (I962). Biochemistry, Easton 1, 373.

Plocke, D. J. \& Vallee, B. L. (1962). Biochemistry, Easton r, 1039.

Price, C. A. \& Vallee, B. L. (1962). Plant Physiol. 37, 428.

Quarterman, J., Williams, R. B. \& Humphries, W. R. (r970). Br. I. Nutr. 24, I049.

Snaith, S. M. \& Levvy, G. A. (I969). Biochem. F. I14, 25.

Todd, W. R., Elvehjem, C. A. \& Hart, E. B. (1934). Am. Y. Physiol. 1o7, r46.

Trubowitz, S., Feldman, D., Morgenstern, S. W. \& Hunt, V. M. (1961). Biochem. F. 80, 369.

Wacker, W. E. C. (1962). Biochemistry, Easton 1, 859 .

Williams, R. B. \& Chesters, J. K. (1970). Br. F. Nutr, 24, 1053.

Williams, R. B. \& Mills, C. F. (I970). Br. F. Nutr. 24, 989.

Wilson, I. B., Dayan, J. \& Cyr, K. (1964). F. biol. Chem. 239, 4 I 82. 